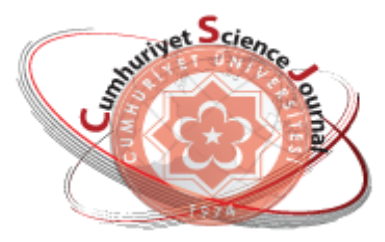

e-ISSN: 2587-246X

ISSN: $2587-2680$

\title{
The First Principles Approach to The Structural, Elastic, Electronic, Vibrational and Thermal Properties of CsCl type-ErAu Alloy
}

\author{
Yesim MOGULKOC ${ }^{1 *}$, Yasemin OZTEKIN CIFTCI ${ }^{2}$ \\ ${ }^{I}$ Department of Engineering Physics, Faculty of Engineering, Ankara University, Ankara / TURKEY \\ ${ }^{2}$ Department of Physics, Faculty of Science, Gazi University, Ankara / TURKEY
}

Received: 07.06.2017; Accepted: 16.06.2017

http://dx.doi.org/10.17776/csj.348288

\begin{abstract}
Lanthanide-gold binary alloys are very attracting attention in applications of electrical measuring technology based on resistance. Such materials are considered suitable for electrical circuits due to the large temperature stability. In this study, the structural, elastic, electronic, vibrational and thermal properties of the CsCl-type crystal structure of the ErAu binary alloy with two atoms in the unit cell are investigated in the framework of the first principles approach. The lattice parameter is found as $3.603 \AA$. Obtained structural parameters are consistent with the available studies. Considering of electronic properties, the electronic band structures, total and partial density of states of the ErAu alloy are determined. From these calculations, it has been decided that ErAu alloy is metallic in nature. The elastic constants are calculated using the stress-strain method. The elastic constants are also obtained for different pressure values. Elastic properties of the system present that ErAu alloy is mechanically stable at different pressure values. Phonon frequencies are calculated and the structure is determined as dynamically stable. To present the thermal properties of ErAu alloy, the free energy, entropy and heat capacity of the system are also obtained under increasing temperature values.
\end{abstract}

Keywords: $\mathrm{CsCl}$ type, ErAu alloy, Structural, Elastic, Electronic, Vibrational, Thermal

\section{ErAu Alaşımının Yapısal, Elastik, Elektronik, Titreşimsel ve Termal Özelliklerine İlk İlkeler Yaklaşımı}

\begin{abstract}
Özet: Lantanit-altın ikili alaşımları, dirence dayalı elektrik ölçüm teknolojilerinin uygulamalarında çok dikkat çekmektedir. Bu tür malzemeler, büyük sıcaklık kararlılığına bağlı olarak elektrik devreleri için uygun kabul edilir. Bu çalışmada, birim hücredeki ErAu ikili alaşımının iki atomlu CsCl-tipli kristal yapısının yapısal, elastik, elektronik, titreşimsel ve termal özellikleri ilk ilkeler yaklaşımı çerçevesinde incelenmiştir. Örgü parametresi $3.603 \AA$ olarak bulunmuştur. Elde edilen yapısal parametreler mevcut çalışmalarla tutarlıdır. Elektronik özelliklerini göz önüne alındığında, elektronik bant yapıları, ErAu alaşımının toplam ve kısmi durumlarının yoğunluğu belirlenir. $\mathrm{Bu}$ hesaplamalardan, ErAu alaşımının metalik özellikte olduğu belirlenmiştir. Elastik sabitler, gerilme-zorlama yöntemi kullanılarak hesaplanmıștır. Elastik sabitler, farklı basınç değerleri için de elde edilmiştir. Sistemin elastik özellikleri ErAu alaşımının farklı basınç değerlerinde mekanik olarak dengeli olduğunu ortaya koymaktadır. Fonon frekansları hesaplanmıştır ve yapı dinamik olarak kararlı olarak belirlenmiştir. ErAu alaşımının termal özelliklerini sunmak için, sistemin serbest enerjisi, entropi ve 1sı kapasitesi artan sıcaklık değerleri altında elde edilmiştir.
\end{abstract}

Anahtar Kelimeler: $\mathrm{CsCl}$ tipi, ErAu, Yapısal, Elastik, Elektronik, Titreşimsel, Termal. 


\section{INTRODUCTION}

Lanthanide-Gold binary intermetallics have many applications by rare earth elements addition [1-4]. Erbium-Gold (ErAu) is one of the binary intermetallic groups from lanthanide-gold [5]. By the way, gold $(\mathrm{Au})$ is one of the noble metals $(\mathrm{Cu}$, $\mathrm{Ag}$ and $\mathrm{Au}$ ) that are very interesting for the material science applications because of the following reasons: The noble metals have high oxidation and corrosion resistance, high stability, good strength, ductility, very high melting points (the melting point of ErAu is around $1700{ }^{\circ} \mathrm{C}$ [5]) and good conductance [5]. High melting points present the high cohesive (binding) property.

Mostly, the intermetallics in CsCl-type crystal structure include one transition metal and a simple metal atom. Lanthanides are the first group of atoms that contain $f$-orbital. ErAu alloy is one of the most stable types of configurations. In addition to, taken into account of some applications with gold by modified rare earth elements, i.e. electronics, gold bonding wire is quite important to support the high purity and it gives a guarantee to supply high bonding properties for mechanical properties [1, 4]. Also, the precision of the electrical resistance materials is one of the other applications to use in potentiometer windings for a stable electrical resistance to get high durability [2-5].

In this work, we have discussed the structural, elastic, electronic, vibrational and thermal properties of the lanthanide-gold intermetallic $\mathrm{ErAu}$ alloy in CsCl-type crystal structure by analyzing first principles calculations. The structural parameters are found quite convenient with other studies and the electronic band structures are determined with density of states. It has been presented that this compound exhibits metallic in the nature. The bond between $\mathrm{Er}$ and $\mathrm{Au}$ atoms are ionic and metallic. Additionally, $\mathrm{ErAu}$ alloy in CsCl-type crystal structure is reported as dynamically stable because of the phonon frequencies are positive. Phonon based thermodynamic properties are also investigated in this study. Free energy, entropy and heat capacitance are determined for different temperature values.

\section{CALCULATION METHOD}

All results have been calculated with using Vienna Ab-initio Simulation Package (VASP) which implements Density Functional Theory (DFT) [68]. The plane wave based pseudo-potential method has been used to calculate the total energies. The electron-ion interactions and the exchange correlation energy are described under the the generalized gradient approximation (GGA) of Perdew Burke Ernzerhof (PBE) scheme, respectively [9-11]. All-electronic projector augmented wave potentials are employed for $\mathrm{Er}$ and $\mathrm{Au}$ elements. The cutoff energy for the plane wave basis set is fixed at $700 \mathrm{eV}$. Ground state atomic geometries are obtained by minimizing the Hellman-Feynman forces using the conjugate gradient method [12, 13]. For all the structures both the lattice parameters and the atomic coordinates have been relaxed ensuring that energies converge to a precision of less than $10^{-10} \mathrm{eV} /$ atom and Hellmann-Feynman forces are less than $10^{-6} \mathrm{eV} / \AA$. The $\mathrm{k}$-point meshes are constructed using the Monkhorst-Pack scheme and the $15 \times 15 \times 15$ k-point meshes are used for the primitive cell of Brillouin zone sampling [14].

\section{RESULTS AND DISCUSSIONS 3.1. Structural and Elastic Properties}

The ErAu binary alloy that contains stoichiometric composition of gold and rare earth metal (Er) has been reported to understand the structural and elastic properties. Atomic positions are important to identify the lattice of the crystal. The unit cell of ErAu alloy is shown in Figure 1. The geometry optimization of the system is carried out using a function of the normal stress by minimizing the total energy of the system. 


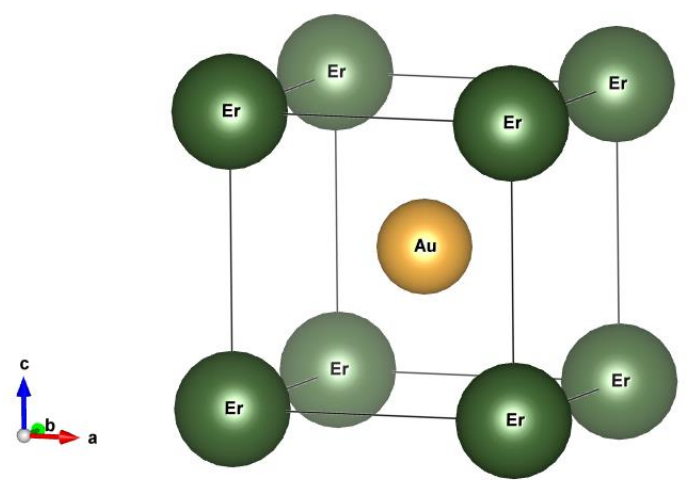

Figure 1. The unit cell of ErAu alloy in CsCl-type crystal structure.

The calculated of lattice constant with GGA-PBE method is obtained as $3.603 \AA$ and is quite convenient with experimental value $(3.527 \AA)$ [15]. For $\mathrm{ErAu}$ alloy in CsCl-type crystal structure, the cohesive energy is calculated as 20.335 Ry in this calculation. The cohesive energy is obtained for binary alloy using the total atom energies are extracted from the total energy of alloy $\left(E_{\text {cohesive }}=E_{\text {total }}-\left(E_{E r}+E_{A u}\right)\right)$.
The energy values versus volume values are indicated in Figure 2. The equilibrium volume value is nearly $158 \mathrm{Bohr}^{3}$ at the minimum energy value.

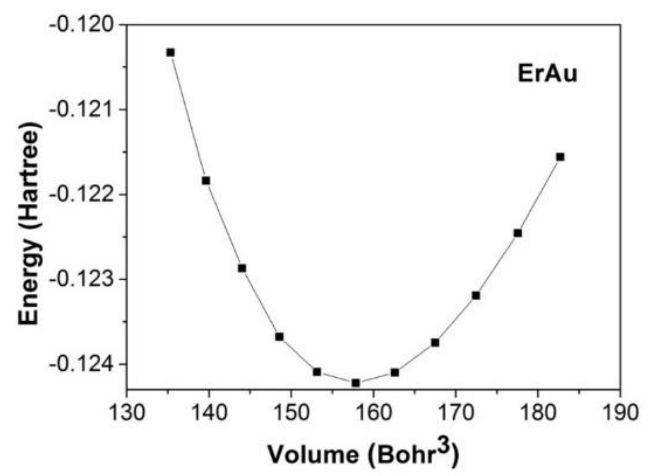

Figure 2. The energy versus volume graph of ErAu alloy.

The equilibrium lattice constant, bulk modulus (B), B/G ratio, second order elastic constants, Young's modulus $(E)$ and Poisson's ratio of ErAu alloy in CsCl-type crystal structure are presented in Table 1

Table 1. Calculated equilibrium lattice constant $(a)$, bulk modulus $(B), \mathrm{B} / \mathrm{G}$ ratio, second order elastic constants, Young's modulus $(E)$ and Poisson's ratio of ErAu alloy.

\begin{tabular}{cccccccccc}
\hline \multirow{2}{*}{ Structure } & Method & $\begin{array}{c}\boldsymbol{a} \\
(\AA)\end{array}$ & $\begin{array}{c}\boldsymbol{B} \\
(\mathbf{G P a})\end{array}$ & $\boldsymbol{B} / \boldsymbol{G}$ & $\begin{array}{c}\boldsymbol{C}_{11} \\
(\mathbf{G P a})\end{array}$ & $\begin{array}{c}\boldsymbol{C}_{12} \\
(\mathbf{G P a})\end{array}$ & $\begin{array}{c}\boldsymbol{C}_{44} \\
(\mathbf{G P a})\end{array}$ & $\begin{array}{c}\boldsymbol{E} \\
(\mathbf{G P a})\end{array}$ & $\boldsymbol{v}$ \\
\hline \multirow{2}{*}{$\mathrm{CsCl}$} & $\begin{array}{c}\text { GGA- } \\
\text { PBE }\end{array}$ & 3.603 & 52.51 & 2.32 & 79.7 & 41.3 & 26.6 & 61.1 & 0.31 \\
\hline
\end{tabular}

The elastic constants reveal that the response of the crystal to external forces and examine the strength and resistivity of the compounds. For this reason, the second order elastic constants are obtained. To calculate the elastic constants through the first-principles calculations from their known crystal structures, there are basically two common methods [16, 17]. One of the approaches is based on the analysis of the total energy of properly strained states of the material in the volume conserving technique and other approach based on the analysis of changes in calculated stress values resulting from changes in the stressstrain technique.

In this study, the stress-strain technique is used to determine the second-order elastic constants $\left(C_{i j}\right)$ of ErAu alloy in CsCl-type crystal structure. The 
stress-strain technique is based on constructing a set of linear equations from stress-strain tensors for several deformations of the unit cell of the system. Given Equation (1) describes that the linear dependency of stress component $\sigma_{i}(i=1-$ 6) and applied strain $\varepsilon_{j}(\mathrm{j}=1-6)$ under small deformations. The crystal structure is fully relaxed under a given set of exchange-correlation potential functions. The equilibrium structure with a minimum total energy is determined.

$$
\sigma_{i}=\sum_{j=1}^{6} c_{j} \varepsilon_{j}
$$

The Born's stability criteria's [18] should be satisfied for the stability of lattice. The known Born's stability conditions of cubic crystals are: $C_{11}>0, \quad C_{11}-C_{12}>0, \quad C_{44}>0, \quad C_{11}+2 C_{12}>0$ and $C_{12}<B<C_{11}$ for mechanical stability. According to the Born's stability conditions, ErAu alloy in CsCl-type crystal structure is mechanically stable using the second order elastic constants for calculations.

It is known that the bulk modulus $(B)$ determines the resistance of material fracture and the shear modulus $(G)$ represents the resistance to the plastic deformation. The $B / G$ ratio is relevant to ductile/brittle behavior for solids. It is well-known that the critical value is 1.75 and/or greater than that value the material is regarded as ductile [1921]. ErAu alloy exhibits the ductile behavior due to the fact that the present value of $B / G$ is 2.32 as given in Table 1 at zero pressure.

Second order elastic constants and related some other elastic properties of ErAu have been estimated as illustrated in Figure 3 for CsCl-type crystal structure. At different pressure values, Born's stability criteria have been approved for ErAu alloy in CsCl-type crystal structure.

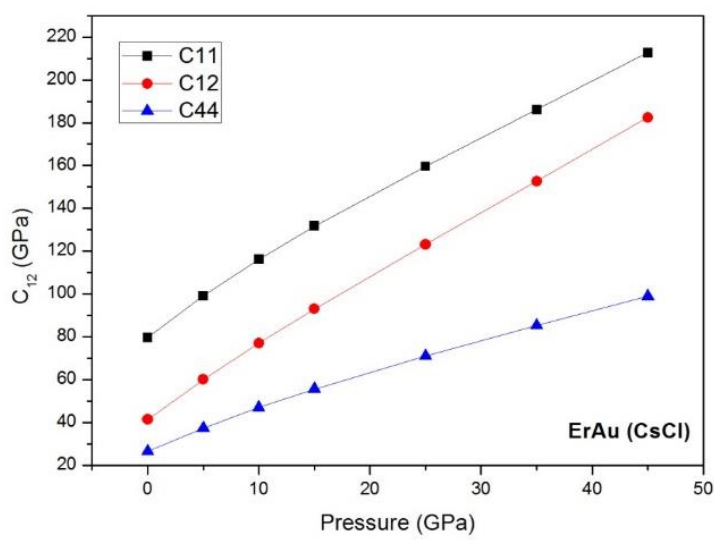

Figure 3. The second order elastic constants versus different pressure values of ErAu alloy.

It is observed that from the Figure 3 , as the pressure increases the elastic constants $C_{11}$ and $C_{12}$ are increased linearly and sharply while $C_{44}$ is normally increased as expected for elastic properties of bulk materials. We have also investigated bulk, shear and Young's modulus under the pressure range from 0 to $45 \mathrm{GPa}$. Until $10 \mathrm{GPa}$, bulk modulus and Young's modulus are increased linearly. The Young's modulus has larger value until $10 \mathrm{GPa}$, after this value Young's modulus is smaller than the bulk modulus value. Shear modulus values are the smallest in the modulus values. For shear modulus values, it can be concluded that the slope has increased slightly. It is completely coherence with reference [22].

According to the Figure 3 and Figure 4, ErAu alloy in CsCl-type crystal structure is mechanically stable under different pressure values from 0 to $45 \mathrm{GPa}$. We have also plotted the $\mathrm{B} / \mathrm{G}$ ratio to show that the ductile behavior under pressure effect. As illustrated in Figure 5, as pressure increases, $\mathrm{B} / \mathrm{G}$ ratio increases at different pressure values. Mechanically, ErAu alloy has the same behavior and stable under the high pressure values. 


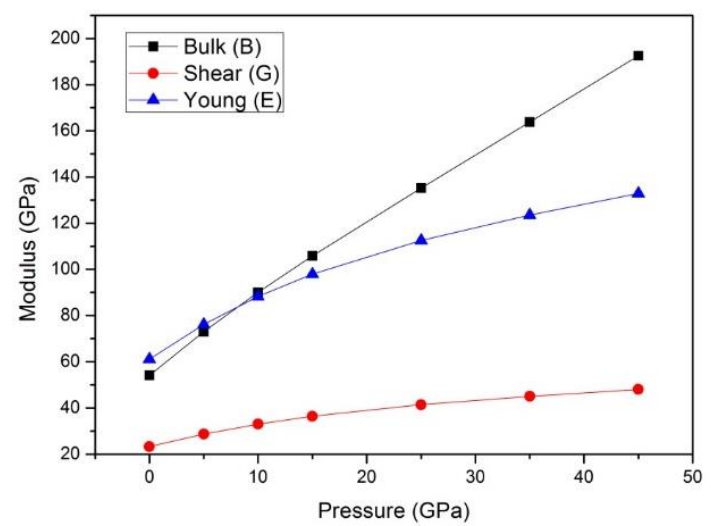

Figure 4. The bulk, shear and Young's modulus versus different pressure values of ErAu alloy.

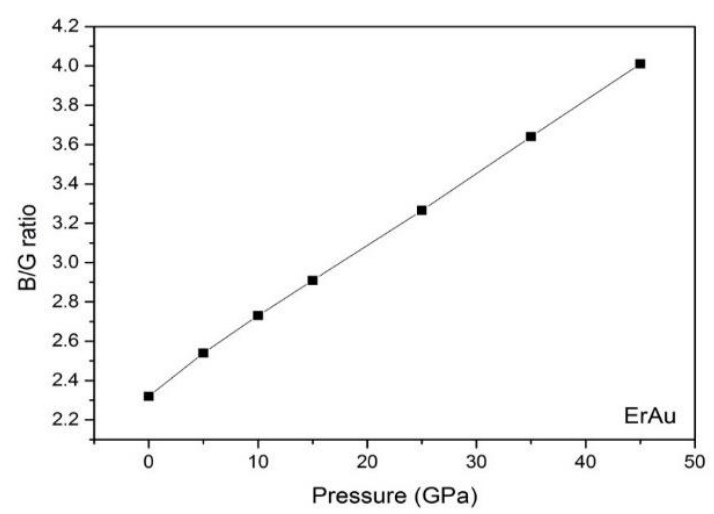

Figure 5. B/G ratios versus different pressure values of ErAu alloy.

The Poisson's ratios of ErAu in CsCl-type structure have also been predicted as shown in Figure 6. It has been observed that the values of Poisson's ratio are increased smoothly at different pressure values. Mostly, Poisson's ratios are changed from 0.3 to 0.5 in metallic behavior. The values are still in this behavior range. Even under high pressures, ErAu alloy in CsCl-type crystal structure shows metallic character.

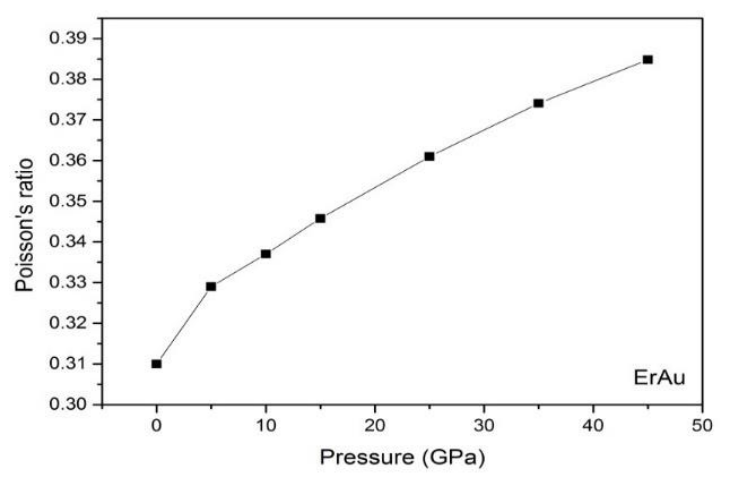

Figure 6. The Poisson's ratios versus different pressure values of ErAu alloy.

\subsection{Electronic Properties}

Electronic structure calculations are performed to evaluate the electronic properties of ErAu alloy in CsCl-type crystal structure along the high symmetry directions in the inclusion of total density of states (DOS) with band structure calculated by GGA scheme as presented in Figure 7. The Figure 7 shows that the ErAu alloy exhibits the metallic nature of the compound due to the fact that band structures are nested at around Fermi level $\left(E_{F}\right)$ that is set to the zero. According to the band structure calculations and density of states (DOS), the band gap is not observed. There is a main peak at around $-5 \mathrm{eV}$ of the total density of states under the Fermi level in valance band region that corresponds to the electronic bands in that region.

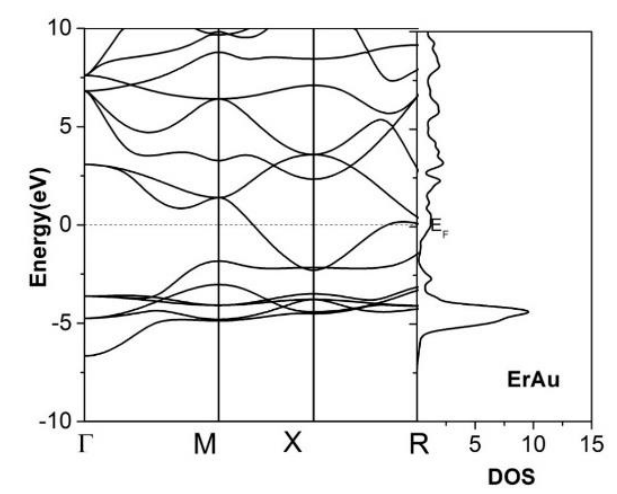

Figure 7. The band structure and density of states of ErAu alloy. 
We also have presented the partial density of states (PDOS) and total density of states (TDOS) of ErAu alloy in CsCl-type crystal structure in Figure 8.

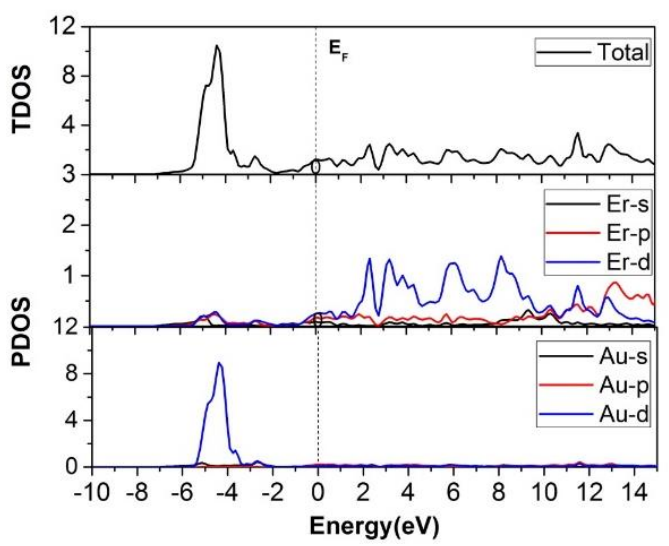

Figure 8. The partial and total density of states of ErAu alloy.

Figure 8 illustrates that the contribution to the lower valance bands and Fermi energy level are mainly Er- $p$ states and Er- $d$ states. The whole calculated width of valance band is nearly $25 \mathrm{eV}$. The conduction bands are mainly from Er- $d$ states and partially Er- $p$ states. Er- $d$ states have many maximums nearly at conduction band values. The ErAu alloy has got a metallic behavior due to the fact that it has no band gap. There is one main peak at around $-5 \mathrm{eV}$ in the valance band region from Au- $d$ states. Au- $d$ states give a huge contribution to the total density of states with small contributions from Er- $d$, Er- $p$ and Er- $s$ states from valance band region.

\subsection{Vibrational and Thermal Properties}

The vibrational properties determine the lattice dynamical stability using the phonon spectra of the materials. The phonon frequencies of ErAu alloy in $\mathrm{CsCl}$ structure have been computed using the PHONOPY code $[23,24]$ that is based on the forces obtained from the VASP. The PHONOPY code calculates force constant matrices and phonon frequencies using the density functional perturbation theory as described in Ref. [24]. The present phonon dispersion curves along several high symmetry directions using a $2 \times 2 \times 2$ cubic supercell of 24 atoms are illustrated in Figure 9. $\mathrm{ErAu}$ alloy in $\mathrm{CsCl}$ crystal system has two atoms in the unit cell, in the phonon spectrum has six phonon branches, including three acoustic branches and three optical branches. Therefore, it strongly supports the dynamical stability of this compound in $\mathrm{CsCl}$ structure. As shown on the right side of Figure 9, the phonon density of the states of the ErAu alloy consists of three groups of bands. The higher modes with frequencies up to $2.0 \mathrm{THz}$ are mixed states composed of the $\mathrm{Er}$ and $\mathrm{Au}$ atoms. In that region, $\mathrm{Er}$ atoms are more dominant than $\mathrm{Au}$ atoms. In the other groups of bands, the contributions are not equal to each other. The modes in the range $0.2-2.0 \mathrm{THz}$ are predominantly determined by the vibrations of the $\mathrm{Au}$ atoms, while the vibrations of the Er atoms are dominant in the upper range. It can be easily concluded that from Figure 9, the general features are consistent with phonon dispersion relations reported for other similar alloys such as in Ref. [15].

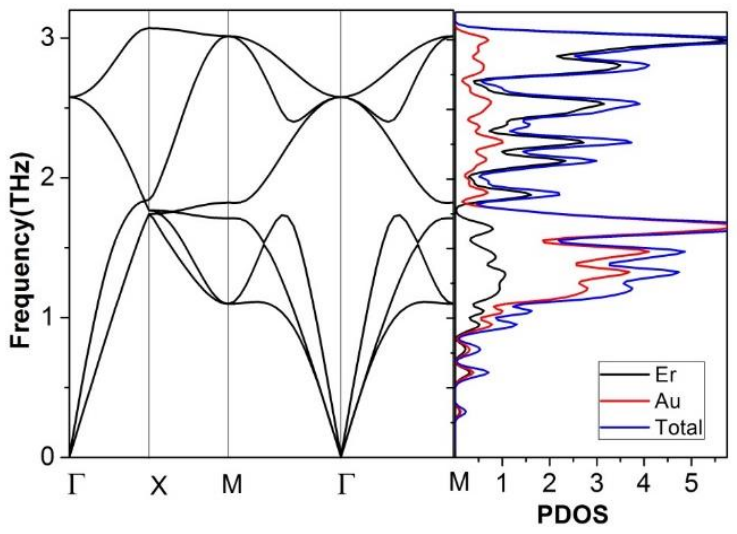

Figure 9. Phonon frequencies and density of states of ErAu alloy.

The temperature dependent properties are also estimated through the thermodynamic quantities based on the quasi-harmonic approach and thermal electronic excitation. By using the phonon frequencies, the thermodynamic parameters such as heat capacity $\left(C_{v}\right)$, entropy $(S)$, and free energy $(F)$ have been determined under quasi-harmonic approximation. As illustrated in Figure 10, the 
free energy values are given versus the increasing temperature values.

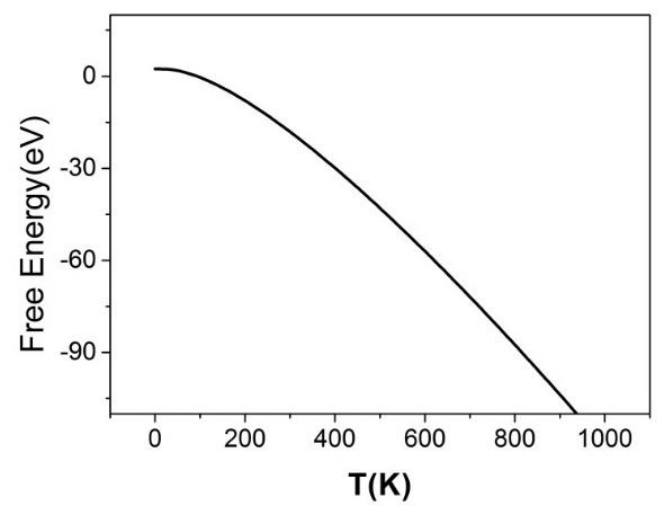

Figure 10. The free energy values of ErAu alloy.

The free energy of the system is important to get information about the thermodynamics of the system which has also known as thermodynamic potential energy. For ErAu alloy in $\mathrm{CsCl}$ crystal structure, temperature values increase free energy decreases.

The contributions from the lattice vibrations to the entropy and the heat capacity of ErAu alloy are also given with Figure 11. To decrease the probable influence of anharmonicity, the temperature is limited to $1000 \mathrm{~K}$. The contribution from the lattice to the heat capacity follows the Debye model and it approaches Dulong-Petit limit at high temperatures.
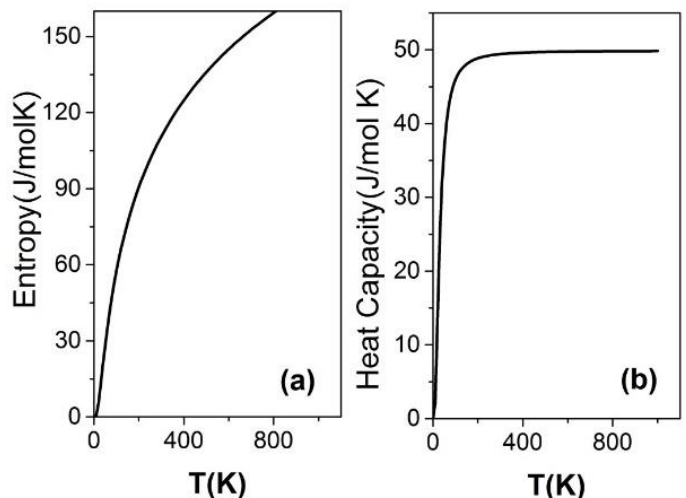

Figure 11. a) Entropy b) heat capacity curves with respect to the temperature of ErAu alloy.

\section{CONCLUSION}

In conclusion, we have performed the structural, elastic, electronic, vibrational and thermal properties of ErAu alloy using first-principles calculations based on the density functional theory with the frame of GGA-PBE. The calculated lattice constant is in good agreement with the existing result from the other related theoretical study that is considered with FP-LAPW method. Second-order elastic constants and other mechanical parameters are obtained and mechanical stability for ErAu alloy is investigated using the Born's stability criteria. As a result, ErAu alloy is determined as mechanically stable. The Born's stability criteria are also investigated under different pressure values with other elastic parameters for ErAu alloy. ErAu alloy exhibits a metallic behavior at zero pressure. Additionally, total and partial densities of states of ErAu alloy are represented and it is shown that main contributions are emerged by Er- $p$ and Er- $d$ states. Also, vibrational and thermal properties of ErAu alloy is investigated and found that ErAu alloy is dynamically stable. Finally, we have deduced that our theoretical results for basic physical properties of ErAu alloy that contributes the applications in materials science for bulk systems.

\section{Acknowledgement}

Y. Mogulkoc acknowledges Ankara University for financial support under AYP with 17A0443001 project number.

\section{REFERENCES}

[1] Corti C.W. Metallurgy of Microalloyed 24 Carat Golds. Gold Bull. 1999; 32: 39-47.

[2] Zhao H., Ning Y. China's ancient gold drugs. Gold Bull. 2001; 34: 24-29.

[3] Ning Y. Properties and applications of some golds alloys modified by rare earth additions. Gold Bull. 2005; 38: 3-8.

[4] Golyev B.B. Synthesis of Alloys, 1st ed. Metallurgy: Moscow, 1984.

[5] Ahmad S., Ahmad R., Jalali-Asadabadi S., Ali Z., Ahmad I. First principle studies of electronic and magnetic properties of 
Lanthanide-Gold (RAu) binary intermetallics. Journal of Magnetism and Magnetic Materials. 2017; 422: 458-463.

[6] Kresse G., Hafner J. Ab initio moleculardynamics simulation of the liquid-metalamorphous-semiconductor transition in germanium. J. Phys. Rev. B. 1994; 49: 14251-14269.

[7] Kresse G., Furthmuller J. Efficient iterative schemes for ab initio total-energy calculations using a plane-wave basis set. Comput. Mater. Sci. 1996; 54: 11169.

[8] Kohn W., Sham L.J. Self-consistent equations including exchange and correlation effects. Phys. Rev. A. 1965; 140: A11331138.

[9] Blochl, P.E. Projector Augmented-wave method. Phys. Rev. B. 1994; 50: $17953-$ 17979.

[10] Kresse G., Joubert D. From ultrasoft pseudopotentials to the projector augmentedwave method. Phys. Rev. B. 1999; 59: 17581775.

[11] Perdew J.P., Burke K., Ernzerhof M. Generalized gradient approximation made simple. Phys. Rev. Lett. 1996; 77: 38653868.

[12] Feynman R.P. Forces in molecules. Phys. Rev. B. 1939; 56: 340-343.

[13] Hellmann H., Introduction to Quantum Chemistry, 1st ed. Deuticke: Leipzig and Wien, 1937.

[14] Monkhorst H.J., Pack J.D. Special points for Brillouin-zone integrations. Phys. Rev. B. 1976; 13: 5188-5192.

[15] Chao C.C., Luo H.L., Duwez P.J. CsCl-type compounds in binary alloys of rare-earth metals with gold and silver. J. of Appl. Phys. 1963; 34: 1971-1973.
[16] Mehl M.J. Pressure dependence of the elastic moduli in aluminum-rich Al-Li compounds. Phys. Rev. B. 1993; 47: 2493-2500.

[17] Wang S.Q., Ye H.Q. Ab initio elastic constants for the lonsdaleite phases of $\mathrm{C}$, si and Ge. Journal of Physics: Condensed Matter. 2003; 240: 45-54.

[18] Born M., Huang K. Dynamical Theory of Crystal Lattices, 1st ed. Clarendon: Oxford, 1954.

[19] Pugh S.F. XCII. Relations between the elastic moduli and the plastic properties of polycrystalline pure metals. Phil. Mag. 1954; 45: 823-843.

[20] Bannikov V.V., Shein I.R. Ivanovskii A.L., Electronic structure, chemical bonding and elastic properties of the first thoriumcontaining nitride perovskite $\mathrm{TaThN}_{3}$. Phys. Status Solidi (RRL). 2007; 1: 89-91.

[21] Johnston I., Keeler G., Rollins R, Spicklemire, S. Solid State Physics Simulations, The Consortium for UpperLevel Physics Software, John Wiley: New York, 1996.

[22] Russell A.M. Ductility in intermetallic compounds. Advanced Engineering Materials. 2003; 5: 629-639.

[23] Togo A., Oba F., Tanaka I. First-principles calculations of the ferroelastic transition between rutile-type and $\mathrm{CaCl}_{2}$-type $\mathrm{SiO}_{2}$ at high pressures. Phys. Rev. B. 2008; 78: 134106.

[24] Togo A., Tanaka I. First principles phonon calculations in materials science. Scripta Materialia. 2015; 108: 1-5. 